\title{
PENERAPAN MODEL PEMBELAJARAN BERPUSAT SISWA DALAM MENGEMBANGKAN KETERAMPILAN PROSES SAINS DAN PEMECAHAN MASALAH SISWA
}

\author{
Wiwid Pungki Ningrum \\ Indyah Sulistyo Arty \\ Universitas Negeri Yogyakarta \\ Email: wiwidpungkiningrum@gmail.com
}

\begin{abstract}
Abstrak: Penelitian ini bertujuan untuk mengungkapkan perbedaan keterampilan proses sains (KPS) dan pemecahan masalah (PM) siswa yang belajar dengan model pembelajaran berpusat siswa (MPBS) dengan siswa yang belajar dengan direct instruction (DI). MPBS diterapkan pada materi asam-basa di kelas XI SMA. Aspek KPS yang diukur ialah observasi, inferensi, merancang percobaan, mengukur, mengkontruksi tabel, dan komunikasi. PM diukur dengan tes yang mengukur proses kognitif $\mathrm{C}_{2}, \mathrm{C}_{3}$ dan $\mathrm{C}_{4}$ dengan dimensi pengetahuan faktual, konseptual dan prosedural. Desain penelitian yang diterapkan ialah post-test control group. Sampel pada kelas kontrol dan kelas eksperimen sebanyak 27 siswa. Kedua data dianalisis dengan MANOVA. Test of between-subjects effects dilakukan pada data PM, sedangkan uji U-Mann Whitney dilaksanakan pada variabel KPS sebab data tidak normal. Hasil menunjukkan pada taraf signifikansi 0,05 tidak terdapat perbedaan yang signifikan pada KPS dan PM siswa pada kedua kelas, namun ada effect size sebesar 0,071. Hasil uji U-Mann Whitney menunjukkan terdapat perbedaan signifikan pada KPS siswa di kedua kelas terutama pada aspek merancang percobaan dan observasi. Test of between-subject effects menunjukkan terdapat perbedaan signifikan pada PM siswa pada kedua kelas, dengan effect size sebesar 5,7\%. Perbedaan PM paling signifikan terdapat pada sub-materi $\mathrm{pH}$ asam kuat dan $\mathrm{pH}$ basa lemah.

Kata Kunci: model pembelajaran berpusat siswa, keterampilan proses sains, PM
\end{abstract}

\section{PENDAHULUAN}

Implementasi kurikulum 2013 perlu diperkuat dengan menerapkan model pembelajaran yang menyediakan pengembangan kompetensi tuntutan abad 21 serta sesuai dengan kerangka pendekatan saintifik. Hal ini disebabkan pada tahun 2045 Indonesia akan didominasi oleh penduduk berusia produktif( (Katuuk, 2014) sehingga pendidikan yang berkualitas saat ini akan memberikan pengaruh yang besar pada masa depan.

Luasnya perkembangan ilmu pengetahuan menuntut output pendidikan memiliki keterampilan untuk memperoleh dan mengembangkan ilmu pengetahuan secara mandiri. Pendekatan saintifik yang dicetuskan dalam kurikulum 2013 dapat mengakomodasi keterampilan tersebut, sayangnya penerapan di sekolah belum sesuai dengan harapan. Di SMA N 2 Banguntapan, pembelajaran kimia masih dilaksanakan dengan pendekatan berpusat guru. Akibatnya, keterampilan berpikir tingkat tinggi siswa kurang terasah, padahal keterampilan ini merupakan bekal penting untuk membangun masa depan. Selain itu, teori dan penerapan suatu konsep kimia masih diajarkan secara terpisah sehingga siswa kurang mengetahui peran kimia dalam kehidupan sehari-hari. Berdasarkan skor performa sains Programme of International Student Assessment (PISA), tahun 2015 siswa di Indonesia memiliki rerata skor 403, lebih rendah dibandingkan negara ASEAN lain seperti Singapura, Malaysia dan Thailand (Education GPS, 2017).

Berdasarkan pemaparan tersebut, sudah saatnya pembelajaran kimia di SMA menerapkan pendekatan pembelajaran yang berpusat siswa, seperti 
pendekatan saintifik. Berbagai penelitian menunjukkan bahwa pendekatan berpusat siswa dapat meningkatkan performa siswa. Contohnya pendekatan inkuiri beroirentasi chemo-enterpreneurship dapat meningkatkan hasil belajar (Supartono, Saptorini, \& Asmorowati, 2009); pendekatan inkuiri dapat meningkatkan keterampilan proses sains (KPS) (Maikristina, Dasna, \& Sulistina, 2013); pendekatan kontekstual dapat meningkatkan hasil belajar dan aktivitas siswa (Pursitasari, 2009), meningkatkan KPS (Wardana, Marhaeni, \& Tika, 2013), meningkatkan literasi (Cigdemoglu \& Geban, 2015), dan mengembangkan karakter (Komalasari, 2012); dan meningkatkan sikap belajar, prestasi belajar dan berpikir kritis (Sung, Hwang, \& Chang, 2015).

Untuk memenuhi tuntutan abad 21 diperlukan pengembangan keterampilan-keterampilan yang berkaitan dengan berpikir tingkat tinggi, seperti KPS dan pemecahan masalah (PM). KPS merupakan keterampilan dalam memperoleh ilmu pengetahuan secara sistematis dan ilmiah seperti yang dilakukan para peneliti (Karsli, Sahin, \& Ayas, 2009; Feyzioglu, 2009; Rauf, Rasul, Mansor, Othman, \& Lyndon, 2013). KPS tidak hanya dilakukan dalam ranah ilmiah namun bisa diterapkan dalam kehidupan (Feyzioglu, 2009).

Berbagai ahli pendidikan telah mengklasifikasi kegiatan-kegiatan yang termasuk dalam KPS menjadi KPS dasar dan KPS terintegrasi (Ergül, et al., 2011; Subali, 2011; Rezba, Sprague, \& Flel, 2003). KPS dasar diantaranya observasi, komunikasi, klasifikasi, mengukur dengan skala baku, inferensi, dan prediksi. KPS terintegrasi diantaranya ialah mengidentifikasi variabel, menyusun tabel data, menggambar grafik, mendeskripsikan hubungan antar variabel, memperoleh dan memproses data, menganalisis eksperimen, menyusun hipotesis, mendefinisikan variabel secara operasional, mendesain investigasi dan melakukan eksperimen (Rezba, Sprague, \& Flel, 2003).

Jika diklasifikasikan berdasarkan tahap pelaksanaannya, KPS dipisahkan menjadi 4 tahap yaitu merencanakan dan memulai yang terdiri dari keterampilan observasi, membandingkan-mengklasifikasi, inferensi, prediksi, memperkirakan, mendeterminasi variabel. Tahap selanjutnya adalah tahap praktik yang terdiri dari aktivitas formulasi hipotesis, mendesain eksperimen, menggunakan pengetahuan tentang materi dan alat, menyusun peralatan eksperimen, mengontrol dan mengubah variabel, mendeskripsikan secara fungsional, mengukur, mengumpulkan informasi dan data, dan merekam data. Tahap analisis dan inferensi terdiri dari aktivitas memproses dan membuat model data, interpretasi dan deduksi serta mempresentasikan data.

Keterampilan PM merupakan suatu keterampilan untuk menyelesaikan beberapa jenis permasalahan yang tidak familiar baik dengan cara konvensional maupun dengan cara inovatif. (Trilling \& Fadel, 2009). Dalam kimia, PM terbagi menjadi PM algoritmik/matematis maupun nonmatematis. Teori PM yang sangat terkenal diajukan oleh Polya (Kim \& Hannafin, 2010) bahwa problem solving terdiri dari memahami masalah, membuat rencana, melaksanakan rencana dan merefleksi pelaksanaannya. PM memiliki asosiasi yang kuat dengan dimensi pengetahuan prosedural, meskipun pada dimensi pengetahuan yang lain PM juga memiliki bagian (Scherer \& Tiemann, 2012).

Model Pembelajaran Berpusat Siswa (Designed Student-Centered 
Instruction) merupakan salah satu pendekatan pembelajaran yang memadukan 3 pendekatan yaitu konstruktivistik, inkuiri dan kontekstual dalam tahapannya (Rahayu, et al., 2011; Rahayu, 2012). Rahayu (2011) menyatakan penerapan model pembelajaran tersebut dapat meningkatkan hasil belajar dan motivasi siswa. Sintaks dalam model pembelajaran tersebut ialah pendahuluan, praktik inkuiri, diskusi kelas dan penerapan. Model pembelajaran ini dapat diterapkan pada berbagai materi kimia di SMA, terutama materi yang mengakomodasi kegiatan eksperimen di laboratorium. Salah satu materi tersebut adalah konsep Asam-Basa, yang diajarkan di kelas XI semester genap. Model pembelajaran ini sangat mendukung kegiatan inkuiri di laboratorium sehingga sangat menunjang pengembangan KPS dan PM siswa.

Penelitian ini bertujuan untuk mengungkapkan adanya perbedaan KPS dan PM siswa yang belajar dengan MPBS terhadap siswa yang belajar dengan direct instruction (DI). di kelas XI SMAN 2 Banguntapan pada materi Asam-Basa. Perbedaan yang diungkapkan baik secara multivariat maupun univariat.

Diharapkan hasil penelitian ini dapat digunakan sebagai referensi ilmiah bagi guru kimia dalam menyelenggarakan pembelajaran dan bagi peneliti dalam mengembangkan ilmu dalam pembelajaran kimia.

\section{METODE PENELITIAN}

Jenis penelitian ini merupakan kuasi eksperimen. Faktor-faktor yang dikontrol dalam penelitian ini ialah: 1) Kelas yang dipilih untuk eksperimen dan kontrol memiliki kesetaraan varians skor kemampuan awal; 2) tidak dilakukan pretest; 3) siswa di kedua kelas berasal dari kelompok umur yang sama, belajar dalam rentang waktu dan durasi yang sama ; 4) siswa belum pernah belajar dengan MBPS; 5) instrumen pengukuran valid dan reliabel; 6) data yang berasal dari siswa yang tidak mengikuti perlakuan secara penuh dihilangkan.

Penelitian dilakukan di kelas XI MIA SMA N 2 Banguntapan, Bantul, DI. Yogyakarta pada semester genap, bulan Januari sampai Februari tahun 2017. Populasi dari penelitian ini adalah seluruh siswa kelas XI IPA SMA N 2 Banguntapan. Sampel diambil dengan cara purposive, yaitu kelas XI MIA 4 sebagai kelas eksperimen dan kelas XI MIA 3 sebagai kelas kontrol.

Desain eksperimen dalam penelitian ini adalah post-test control group. Penelitian dilakukan terhadap siswa kelas XI SMAN 2 Banguntapan, Bantul pada materi Asam-Basa. Terdapat dua kelas yang dipilih karena memiliki kemampuan awal yang tidak berbeda secara statistik. Salah satu kelas sebagai kelas eksperimen dan kelas lain sebagai kelas kontrol. Kelas eksperimen diberi perlakuan dengan MPBS, sedang kelas kontrol dengan model pembelajaran KTSP. MPBS dilakukan dengan level inkuiri ke-3 Le Roy \& Lee (Rahayu, 2012). Masing-masing kelas mempelajari konsep Asam-Basa sebanyak 6 kali pertemuan. Pengukuran KPS dilakukan dengan observasi dan tes tertulis, sedangkan PM diukur dengan tes.

Data yang dikumpulkan berupa skor KPS dan skor PM. Instrumen yang digunakan berupa lembar observasi KPS dan lembar soal KPS dan PM. Lembar observasi KPS digunakan saat praktikum terdiri dari aspek observasi, mengukur, menyusun tabel, menyusun prosedur kerja, menyimpulkan dan komunikasi. Lembar observasi berbentuk checklist sebanyak 24 butir dikembangkan berdasar 
aspek KPS terpilih. Lembar observasi telah divalidasi oleh 2 orang ahli pembelajaran kimia. Observasi KPS dilakukan sebanyak 3 kali untuk 3 kali kegiatan praktik laboratorium.

Lembar soal disusun secara terintegrasi, terdiri dari soal yang mengukur KPS sebanyak 8 butir dan soal yang mengukur PM sebanyak 10 butir. Soal tersebut divalidasi isi melalui expert judgement dan uji empiris. Analisis validitas dan reliabilitas soal dengan metode Rasch berbantuan software Winstep. Soal terdiri dari dua paket, paket A memiliki reliabilitas 0,79 dan paket B memiliki reliabilitas 0,89 . Soal post-test diujikan di akhir pertemuan.

\section{Teknik Analisis Data}

Dilakukan uji MANOVA dengan bantuan SPSS untuk mengetahui adanya perbedaan yang signifikan antara PM dan KPS siswa antara kelas eksperimen dan kelas kontrol. Hasil tes yang dibaca pada tabel main effects dan between-subjects effect. Main effect menunjukkan pengaruh perlakuan terhadap kedua variabel secara bersama-sama, sedangkan betweem subjects effect menunjukkan efek perlakuan terhadap masing-masing variabel. Selain itu dilakukan uji U-Mann Whitney untuk mengetahui perbedaan pada skor total KPS. Letak perbedaan pada masing-masing variabel yaitu PM dan KPS antara kedua kelas dilihat dengan cara melakukan uji U-Mann Whitney. PM dipisahkan pada skor setiap sub-materi Asam-Basa. Skor dipisahkan berdasar sub-materi : 1) teori asam basa; 2) $\mathrm{pH}$ asam kuat; 3) $\mathrm{pH}$ basa kuat; 4) $\mathrm{pH}$ asam lemah dan; 5) $\mathrm{pH}$ basa lemah. Skor KPS dipisahkan berdasarkan aspek 1) mengukur, 2) observasi, 3) merancang tabel pengamatan, 4) merancang prosedur percobaan dan 5) menyimpulkan.

\section{HASIL DAN PEMBAHASAN}

MPBS terlaksana sebesar $90 \%$ dari keseluruhan langkah yang didesain peneliti. Pelaksanaan model pembelajaran optimal pada tahap pendahuluan, praktik inkuiri, sedangkan pada tahap diskusi kelas dan penerapan belum berjalan optimal. Pada tahap diskusi kelas, keterbatasan waktu belajar dan kurangnya aktivitas diskusi siswa menjadi penyebab rendahnya KPS pada aspek komunikasi lisan. Pada tahap penerapan, dilakukan secara sederhana dan dalam bentuk penugasan disebabkan keterbatasan waktu.

Hasil uji normalitas pada kedua variabel ialah memenuhi normalitas secara multivariat, namun uji normalitas pada masing-masing variabel menunjukkan data PM berdistribusi secara normal, namun data KPS tidak berdistribusi normal. Sehingga, uji MANOVA tetap dilaksanakan, namun KPS secara univariat diuji secara nonparametrik. Adapun kedua data memiliki varians yang homogen baik dengan uji Box M maupun dengan uji Levene.

Uji MANOVA menunjukkan p-value sebesar 0,057. Nilai ini lebih besar daripada 0,05 , sehingga hipotesis nol diterima. Artinya, tidak terdapat perbedaan yang signifikan pada KPS dan PM siswa yang belajar dengan MPBS terhadap siswa yang belajar dengan DI. Hasil ini menjelaskan bahwa tidak ada perbedaan antara PM dan KPS secara bersamaan yang dapat membedakan kedua kelompok sampel.

Hasil test of between-subjects effect menunjukkan terdapat perbedaan PM 
yang signifikan antara siswa yang belajar dengan MPBS dengan siswa yang belajar dengan DI, dengan p-value sebesar 0,032 dan effect size 5,7\%. Hal ini menunjukkan, penerapan MPBS memberikan pengaruh pada pemecahan masalah siswa. Rerata PM siswa yang belajar dengan MPBS lebih tinggi dibandingkan dengan siswa yang belajar dengan DI. Hasil ini sesuai dengan penelitian yang dilakukan oleh Rahayu (2011) yang menunjukkan bahwa terdapat peningkatan prestasi belajar pada siswa yang belajar dengan designed student-centered instruction (DSCI). Hasil uji U-Mann Whitney pada variabel PM ditunjukkan pada Tabel 1.

Berdasarkan Tabel 1, Perbedaan yang signifikan dalam PM terdapat pada skor $\mathrm{pH}$ asam kuat dan $\mathrm{pH}$ basa lemah. Hasil validasi empiris soal pada kedua sub-materi tersebut termasuk kategori sukar. Dapat disimpulkan bahwa siswa di kelas eksperimen Pada sub-materi lain tidak terdapat perbedaan yang signifikan, namun rerata kelas eksperimen pada seluruh materi lebih tinggi dibandingkan dengan kelas kontrol. Perbandingan rerata skor antara kedua kelas dengan jelas dapat dilihat pada Gambar 1.

\begin{tabular}{|c|c|c|c|}
\hline \multicolumn{4}{|c|}{ Tabel 1. Hasil Uji U-Mann Whitney } \\
\hline No & Statistik & $\mathbf{U}$ & Signifikansi \\
\hline 1 & $\begin{array}{l}\text { Rangking } \\
\text { PAK }^{1)}\end{array}$ & 250,50 & 0,040 \\
\hline 2 & $\begin{array}{l}\text { Rangking } \\
\text { PAL }^{2)}\end{array}$ & 280,50 & 0,144 \\
\hline 3 & $\begin{array}{l}\text { Rangking } \\
\text { PBK }^{3)}\end{array}$ & 315,00 & 0,390 \\
\hline 4 & $\begin{array}{l}\text { Rangking } \\
\text { TAB }^{4)}\end{array}$ & 335,50 & 0,599 \\
\hline 5 & $\begin{array}{l}\text { Rangking } \\
\mathrm{PBL}^{5)}\end{array}$ & 242,00 & 0,033 \\
\hline
\end{tabular}

Keterangan :

1) $\mathrm{pH}$ Asam Kuat

2) $\mathrm{pH}$ Asam Lemah

3) $\mathrm{pH}$ Basa Lemah

4) Teori Asam Basa

5) $\mathrm{pH}$ Basa Lemah

Kelas eksperimen memiliki rerata PM yang lebih tinggi karena siswa mempelajari konsep asam basa dengan lebih aktif. Siswa dilatih untuk menemukan jawaban atas konsep yang perlu dikuasai secara lebih mandiri. Selain itu, dilakukan diskusi kelas dan penguatan terhadap jawaban-jawaban siswa oleh guru. Pada tahap pendahuluan diterapkan pendekatan konstruktivistik yang membantu siswa memahami konsep asam basa dengan lebih baik, sehingga pemecahan masalah menjadi lebih terasah. 


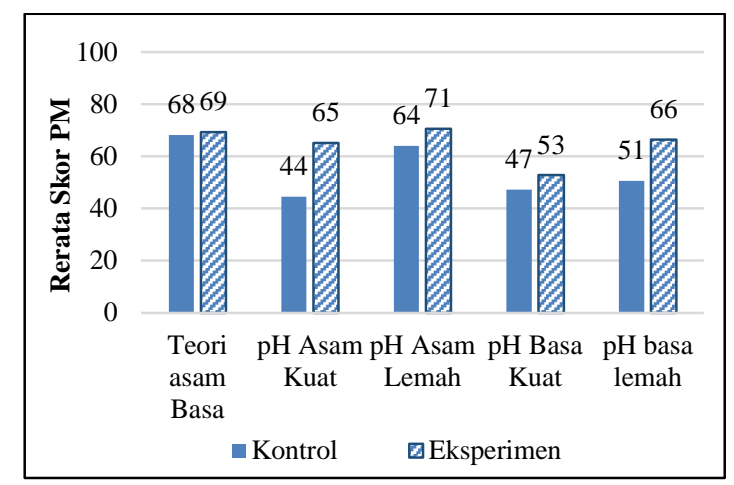

Gambar 1. Perbandingan Skor PM

Hasil uji Mann-Whitney pada KPS menunjukkan nilai signifikansi sebesar 0,044. Nilai ini lebih kecil dari 0,050 sehingga dapat disimpulkan terdapat perbedaan yang signifikan pada KPS siswa yang belajar dengan MPBS dengan siswa yang belajar dengan DI di SMA N 2 Banguntapan. Siswa di kelas eksperimen memiliki rerata KPS yang lebih tinggi dibandingkan dengan rerata KPS kelas kontrol. Perbedaan yang signifikan pada KPS terutama disebabkan oleh adanya kegiatan praktik inkuiri dalam MPBS. Kegiatan ini melatih KPS siswa secara langsung, mulai dari mengidentifikasi tujuan percobaan, mrancang langkah kerja dan tabel pengamatan, mengamati, mengukur, mengkomunikasikan hasil pengamatan, dan menyimpulkan. Hal ini sesuai dengan penelitian oleh Özer \& Özkan (2013) yang melaksanakan Project Based Learning (PjBL). PjBL memiliki kesamaan dengan DSCI yaitu adanya inkuiri ilmiah. Hasil penelitiannya menunjukkan bahwa guru lebih berhasil mengembangkan KPS pada aspek estimasi; hipotesis; memilih, melakukan determinasi, dan mengubah variabel; mengukur, menghubungkan spasial dan numeral; merekam data, mendidesain uji dan menginterpretasi

Hasil pada kedua uji untuk PM dan KPS diatas menunjukkan adanya efek yang signifikan dalam penerapan MPBS, namun MPBS tidak menyebabkan terjadinya interaksi antara kedua variabel, sehingga efeknya secara multivariat tidak signifikan. Meskipun tidak signifikan, terdapat effect size sebesar 7,1\%.

Untuk mengetahui letak perbedaan KPS antara kedua kelas, dilakukan uji U-Mann Whitney pada aspek mengukur, mengamati, mengkontruksi tabel, merancang prosedur percobaan, dan menyimpulkan dalam KPS. Tabel 2 menunjukkan hasil uji tersebut.

\begin{tabular}{|c|c|c|c|}
\hline No & Statistik & $\mathbf{U}$ & Signifikansi \\
\hline 1 & Rangking Mengukur & 316,5 & 0,301 \\
\hline 2 & Rangking Observasi & 253,5 & 0,005 \\
\hline 3 & Rangking Inferensi & 349 & 0,779 \\
\hline 4 & $\begin{array}{l}\text { Rangking Merancang } \\
\text { Percobaan }\end{array}$ & 232 & 0,015 \\
\hline 5 & $\begin{array}{l}\text { Rangking } \\
\text { Mengkontruksi Tabel }\end{array}$ & 356 & 0,821 \\
\hline
\end{tabular}

Hasil tersebut menunjukkan bahwa siswa di kelas kontrol memiliki 
keterampilan observasi dan merancang percobaan yang berbeda secara signifikan dengan kelas eksperimen. Siswa di kelas eksperimen memiliki keterampilan yang lebih baik pada aspek observasi dan merancang percobaan, disebabkan adanya kegiatan praktik inkuiri yang menuntut siswa merancang langkah kerja dalam percobaan. Pada aspek lain tidak terdapat perbedaan yang signifikan. Secara lebih jelas, rerata KPS pada setiap aspek ditunjukkan pada gambar 2. Kelas eksperimen justru memiliki rerata yang lebih rendah dalam aspek inferensi dan tabel. Aspek inferensi lebih rendah sebab tahap memahamkan siswa terhadap tujuan percobaan belum efektif. Akibatnya, kesimpulan yang ditulis oleh siswa tidak terlalu sesuai dengan tujuan percobaan.

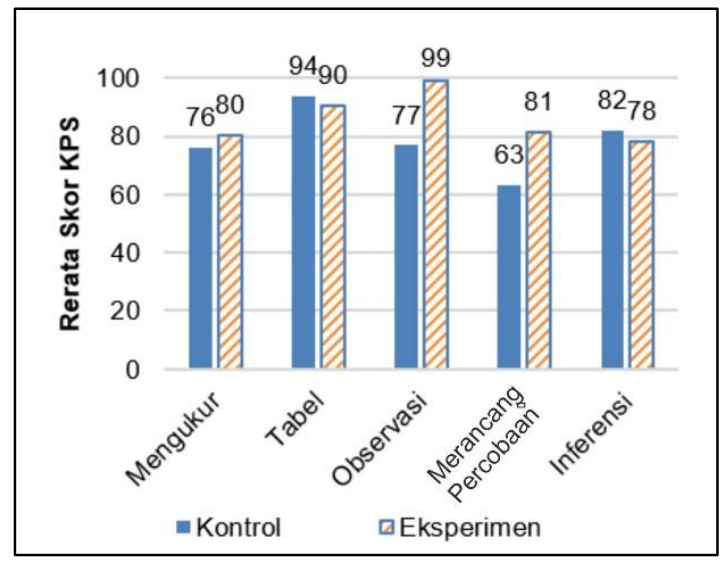

Gambar 2. Perbandingan Skor KPS

Berdasarkan pemaparan hasil penelitian, ditunjukkan bahwa terdapat perbedaan yang signifikan dalam setiap aspek keterampilan proses sains dan aspek pemecahan masalah siswa. Signifikansi pada pemecahan masalah sangat terlihat terutama pada persoalan tentang $\mathrm{pH}$ asam kuat dan basa lemah. Hal ini menunjukkan siswa yang belajar dengan MPBS memiliki kemampuan yang lebih baik dalam mengerjakan soal-soal sukar. Adapun pada kketerampilan proses sains, siswa lebih terampil dalam merancang percobaan dan observasi. Hal ini disebabkan dalam pembelajaran MPBS siswa dilatih dalam merancang percobaan melalui pendekatan inkuiri. Dalam MPBS, proses inkuiri diwakili melalui kegiatan ilmiah yang tercermin dalam rancangan percobaan.

\section{KESIMPULAN DAN SARAN}

\section{Kesimpulan}

Tidak terdapat perbedaan yang signifikan secara bersama-sama dalam PM dan KPS siswa yang belajar dengan MPBS (kelas eksperimen) dengan siswa yang belajar dengan DI (kelas kontrol), namun siswa di kelas eksperimen memiliki PM yang lebih baik secara signifikan dibandingkan dengan siswa di kelas kontrol, dengan effect size 5,7\%. Siswa di kelas eksperimen lebih mampu menyelesaikan soal sukar pada sub-materi $\mathrm{pH}$ asam kuat dan $\mathrm{pH}$ basa lemah. KPS siswa di kelas eksperimen ini secara keseluruhan lebih baik dibandingkan KPS siswa kelas kontrol terutama pada aspek observasi dan merancang percobaan. 


\section{Saran}

Model pembelajaran berpusat siswa dapat mengembangkan PM dan KPS siswa, yang merupakan kompetensi yang amat dibutuhkan pada abas XXI. Oleh sebab itu, guru perlu menerapkan mode-model pembelajaran yang dapat mengasah kompetensi abad XXI, salah satunya adalah MPBS. Dalam penerapan model pembelajaran berpusat siswa, sebaiknya guru perlu memperhatikan dengan baik cara memahamkan tujuan percobaan kepada siswa agar siswa dapat menyimpulkan hasil percobaan secara tepat sasaran. Selain itu, dapat dilakukan penelitian dengan membandingkan penerapan MPBS pada level inkuiri yang berbeda.

\section{DAFTAR PUSTAKA}

Cigdemoglu, C., \& Geban, O. (2015). Improving students' chemical literacy levels on thermochemical and thermodynamics concepts through a context-based approach. Chemistry Research and Practice, 16(2), 302317. doi:10.1039/C5RP00007F

Ergül, R., Simsekli, Y., Calis, S., \& Ozdilek, Z. (2011). The effects of inquirybased science teaching on elementary school students' science process Skills and science attitudes. Bulgarian Journal of Science and Education Policy, 5(1), 48-68.

Feyzioglu, B. (2009). An investigation of the relationship between science process skills with efficient laboratory use and science achievement in chemistry education. Turkish Science Education, 6(3), 114-132.

GPS, E. (2017, 04 19). Education GPS. Diambil kembali dari OECD: http://gpseducation.oecd.org/

Karsli, F., Sahin, C., \& Ayas, A. (2009). Determining science teachers' ideas about the science process: A case study. Procedia Social and Behavioral Science, 890-895. doi:https://doi.org/10.1016/j.sbspro.2009.01.158

Katuuk, D. A. (2014). Manajemen implementasi kurikulum: Strategi penguatan implementasi kurikulum 2013. Cakrawala Pendidikan, 1(XXXIII), 12-26.

Kim, M. C., \& Hannafin, M. J. (2010). Scaffolding problem solving in technology-enhanced learning environments (TELEs): Bridging research and theory with practice. Computers \& Education Journal, 56(2011), 403417.

Komalasari, K. (2012). The Living Values-Based Contextual Learning to Develop the Students' Character. Journal of Social Sciences, 8(2), 246-25.

Maikristina, N., Dasna, I. W., \& Sulistina, O. (2013). Pengaruh penggunaan model pembelajaran inkuiri terbimbing terhadap hasil belajar dan keterampilan proses sains siswa kelas XI IPA SMA N 3 Malang pada materi hidrolisis garam. Jurnal Universitas Negeri Malang. Diambil kembali dari jurnalonline.um.ac.id/data/artikel/artikel68099EE989A697168C97626B63B8B4 E4.pdf

Özer, D. Z., \& Özkan, M. (2013). The effect of project based learning method on science process skills of prospective teachers of science education in biology lessons. International Online Journal of Educational Sciences, 
5(3), 635-645.

Pursitasari, I. D. (2009). Peningkatan aktivitas dan pemahaman siswa dalam pembelajaran kimia melalui pendekatan kontekstual. Jurnal Ilmu Pendidikan, 3(16), 172-177. doi:http://dx.doi.org/10.17977/jip.v16i3.2570

Rahayu, S. (2012). Designed student-centered instruction (DSCI): Model pembelajaran berbasis konstruktivistik, inkuiri dan kontekstual. Seminar Nasional Kimia dan Pendidikan Kimia, (hal. 1-16). Surakarta.

Rahayu, S., Chandrasegaran, A., Treagust, D. F., Ibnu, S., \& Kita, M. (2011). Understanding acid base concept : Evaluating the efficacy of the senior high school student-centred instructional program in Indonesia. International Journal of Science and Mathematics Education, 1439-1458.

Rauf, R. A., Rasul, M. S., Mansor, A. N., Othman, Z., \& Lyndon, N. (2013). Inculcation of science process skills in a science classroom. Asian Social Science, 47-57.

Rezba, R. J., Sprague, C., \& Flel, R. (2003). Learning and assess science process skill. Iowa: Kendall/Hunt.

Scherer, R., \& Tiemann, R. (2012). Factors of problem-solving competency in a virtual chemistry environment: The role of metacognitive knowledge about strategies. Computers and Education, 59(4), 1199-1214. doi:10.1016/j.compedu.2012.05.020

Subali, B. (2011). Pengukuran kreativitas keterampilan proses sains dalam konteks assesment for learning. Cakrawala Pendidikan, 130-144.

Sung, H.-Y., Hwang, G.-J., \& Chang, H.-S. (2015). An integrated contextual and web-based issue quest approach to improving student's learning achievements, attitudes and critical thinking. Educational Technology \& Society, 18(4), 299-311.

Supartono, Saptorini, \& Asmorowati, D. S. (2009). Pembelajaran kimia menggunakan kolaborasi inkuiri dan konstruktif berorientasi chemoenterpreneurship. Jurnal Inovasi Pendidikan Kimia, 2(3), 476-483.

Trilling, B., \& Fadel, C. (2009). 21 st century skill : Learning for life in our times. California: John Wiley \& Sons.

Wardana, I. K., Marhaeni, A. A., \& Tika, I. N. (2013). Pengaruh model kontekstual terhadap keterampilan proses sains dan hasil belajar sains pada siswa kelas IV SD Gugus V DR. Suetomo. e-Journal Program Pascasarjana Universitas Pendidikan Ganesha Prodi Pendidikan Dasar. Diambil kembali dari http://pasca.undiksha.ac.id/ejournal/index.php/jurnal_pendas/article/view/713 